\title{
Error Analysis of Korean-English Bilingual Children's Speech Productions
}

\author{
Jae-Hyun Kim¹, Elaine Ballard², Clare McCann² \\ ${ }^{1}$ James Cook University, Australia; ${ }^{2}$ University of Auckland, New Zealand
}

Purpose: Type of surface-level speech errors can be diagnostically valuable information to identify children with speech sound disorder (SSD). There is a lack of such information for bilingual children, which makes identifying bilingual children with SSD a significant challenge. This article reports on error production in Korean-English bilingual (KEB) children.

Methods: Single-word samples were collected from 52 KEB children aged between 3;0 and 7;11. The word productions were analysed for error and compared to the existing date from monolingual English-speaking (ME) and monolingual Korean-speaking (MK) children.

Results: While some children's error production was similar to what would be expected in respective monolingual children, other children produced errors that would be considered delay, atypical or even advanced for their monolingual counterparts in both of their languages. No reliable factors could be identified to determine the characteristics associated with delay, atypical or advanced error production compared to monolingual children.

Conclusions: There are qualitative differences in phonological development between monolingual and bilingual children. The clinical use of available monolingual normative data is likely to lead to an inaccurate diagnosis of SSD. Small cohort studies in bilingual phonological development should not be taken as normative data in clinical practice due to heterogeneity.

Keywords: Phonological development, Error patterns, Speech sound disorders, Bilingualism

\section{INTRODUCTION}

Children acquire the phonological systems of the languages to which they are exposed in their own natural environments, regardless of the number of languages they are learning $[1,2]$. A clinically significant deviation from typical phonological development is known as speech sound disorder (SSD) [3,4]. According to the Differential Diagnosis System (DDS), the best criterion to determine whether a child's phonological development is typical or not is the surface-level speech error patterns [5]. Children who produce error patterns that are common and typical in the normative sample but used only by a younger age group are considered to have phonological delay. Those who produce error patterns that are infrequent and atypical are considered to have phonological disorder [5-7]. Different subgroups of SSD reflect distinct underlying processing deficits [811 ] and respond differentially to different types of treatment [12-14]. Therefore, effectiveness of treatment for children with SSD is contingent on accurate differential diagnosis. The availability of information regarding typical, developmental error patterns in bilingual children is scarce. This places bilingual children at risk of misdiagnosis.

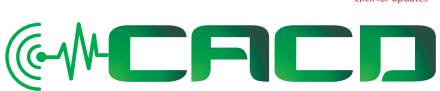

Received: October 3, 2016 Revision: November 15, 2016 Accepted: November 15, 2016

\section{Correspondence:}

Jae-Hyun Kim

College of Healthcare Sciences, James Cook University, 1 James Cook Drive Townsville, QLD 4811, Australia Tel: +61-7-4781-6490

E-mail: jae-hyun.kim@jcu.edu.au

(C) 2016 The Korean Association of SpeechLanguage Pathologists

This is an Open Access article distributed under the terms of the Creative Commons Attribution Non-Commercial License (http:// creativecommons.org/licenses/by-nc/4.0/) which permits unrestricted non-commercial use, distribution, and reproduction in any medium, provided the original work is properly cited. 


\section{Error production in bilingual children}

Table 1 summarises the main findings of articles reporting on error production in bilingual children. There is no universally accepted procedure for analysing errors [15]. As such, there are differences in the methodology used for error analysis in the articles listed in Table 1. Studies with a large sample size were rare. The youngest children to be studied were two-yearold bilingual children [16] and the oldest children were Japanese-Korean bilingual children with the mean age of 8.2 years [17]. The most studied bilingual population was Spanish-English bilingual children, followed by Cantonese-English bilingual children.

Hambly, Wren [2] concluded that there were qualitative differences in phonological development between bilingual and monolingual children and therefore would suggest that error production in bilingual and monolingual children should be different. At least five studies, however, found that error patterns in bilingual children were similar to monolingual children in at least one language. Three separate studies on Putonghua-English bilingual children [18], Putonghua-Cantonese bilingual children [19], and Spanish-English bilingual children [20] found no obvious differences in error production between bilingual and monolingual children. Grech and Dodd [16] reported that the error patterns produced by Maltese-English bilingual children were similar to their monolingual counterparts, but only for younger children. Older bilingual children produced fewer types of errors than monolingual children. Both Goldstein and Washington [21] and Goldstein and Bunta [22] found that Spanish-English bilingual children demonstrated more advanced phonological skills in English but worse or commensurate skills in Spanish, compared to their respective monolingual counterparts.

Gildersleeve-Neumann, Peña [23] also reported that there was no obvious impact on error patterns affecting consonants and syllable structures produced by Spanish-speaking children after they were exposed to English. However, they found an increase in vowel errors following exposure to English. Error patterns that are typical of monolingual children have been found to be resolved at an older age or produced at a greater frequency in bilingual children in many studies [17, 21,24-30]. Therefore, the delayed resolution of typical error patterns may reflect a characteristic of typical phonological development in bilingual children rather than phonological delay as described in the DDS [5].

Other studies have found that bilingual children produced error patterns that were deemed atypical in monolingual children in at least one of their languages [25-27,30-32]. For example, substitution of glottal stop, word initial consonant deletion and backing have been reported in bilingual children [25-27,31]. In ME children, such error patterns would be indicative of a phonological disorder [5].

The studies reviewed in Table 1 have produced discrepant results with regards to whether bilingual children produce 'atypical' or 'delayed' error patterns. ${ }^{1)}$ The literature points to at least three factors to consider for why the findings have been so inconsistent. The first is language dominance. Language dominance is defined as the language of the greatest exposure [33]. Both Lin and Johnson [18] and So and Leung [30] found that language dominance played a crucial role, despite the different findings between these two studies (see Table 1). They suggested language dominance "may help to prevent unusual speech patterns from occurring" [18] and that dominant language should be less influenced by bilingualism [30]. On the other hand, Law and So [19] specifically addressed the issue of language dominance with 100 bilingual children and found that bilingual children produced typical error patterns comparable to monolingual children, regardless of language dominance.

The second potential factor influencing error production in bilingual children is the age of language acquisition. The Interactional Dual Systems model assumes that simultaneous bilingual children have two separate phonological systems from the onset of phonological development [33-35]. For sequential bilingual children, however, the second language phonology was thought to be established initially by superimposing the second language phonology onto the first language phonology $[36,37]$. Goldstein and Gildersleeve-Neumann [38] suggested that cross-linguistic effects and differences from monolingual phonological development would be more pronounced in sequential bilingual children. Empirical data so far have suggested otherwise. A regression analysis conducted by Holm and Dodd [27] found that age of second language acquisition was not a statistically significant factor in bilingual phonological development. Gildersleeve-Neumann, Peña [23] found that sequential Spanish-English bilingual children were comparable to simultaneous Spanish-English bilingual children

\footnotetext{
1) Single quotation marks are used for scare quotes to imply that the word enclosed with single quotation marks may not signify its apparent meaning in this article. When it is stated that bilingual children produced 'atypical' error patterns, this is to mean that bilingual children produced error patterns deemed atypical for their monolingual counterparts. It does not imply that those error patterns are necessarily atypical of the bilingual children.
} 
Table 1. Error production in bilingual children

\begin{tabular}{|c|c|c|}
\hline Study & Participants & Major findings \\
\hline Anderson [44] & $\begin{array}{l}\text { Five sequential bilingual children } \\
\text { with various first languages } \\
(3 ; 9-4 ; 9)\end{array}$ & $\begin{array}{l}\text { Four children produced unusual non-target responses in English, including substituting [w] } \\
\text { for } / \mathrm{v} / \text {, dentalisation of alveolar fricatives, lateralisation of fricatives and affricates. } \\
\text { Voicing errors were identified in one child (i.e. delayed). Unusual errors were also } \\
\text { identified in their first languages, including aspiration of postvocalic unreleased stops } \\
\text { in Korean. }\end{array}$ \\
\hline Brice et al. [22] & $\begin{array}{l}16 \text { simultaneous Spanish-English } \\
\text { bilinguals aged four and five } \\
\text { years }\end{array}$ & $\begin{array}{l}\text { Bilingual children were different from monolingual children. Occurrences of velar fronting } \\
\text { and stopping were higher in English. Interference was uncommon. }\end{array}$ \\
\hline Dodd et al. [23] & $\begin{array}{l}16 \text { Cantonese-English bilinguals } \\
(2 ; 1-4 ; 3)\end{array}$ & $\begin{array}{l}\text { Some (but not all) bilinguals produced error patterns that would indicate delayed or } \\
\text { atypical development in monolingual children. Cantonese was more susceptible to } \\
\text { delayed and atypical errors, even though the children spoken Cantonese as their first } \\
\text { language. }\end{array}$ \\
\hline $\begin{array}{l}\text { Gildersleeve-Neumann et al. } \\
\text { [24] }\end{array}$ & $\begin{array}{l}23 \text { English-Spanish bilinguals } \\
(3 ; 0-3 ; 10) \text {, assessed twice }\end{array}$ & $\begin{array}{l}\text { Cross-linguistic competition influences erroneous productions, with a higher frequency of } \\
\text { errors in bilinguals than in their monolingual counterparts. However, bilingual children } \\
\text { produced error patterns that were not due to a cross-linguistic effect, such as the } \\
\text { substitution of glottal stop for a word-final consonant (only English was investigated). }\end{array}$ \\
\hline $\begin{array}{l}\text { Gildersleeve-Neumann et al. } \\
\text { [21] }\end{array}$ & $\begin{array}{l}\text { Six Spanish-speaking children } \\
\text { (3;2-3;10) assessed twice before } \\
\text { and after English exposure }\end{array}$ & $\begin{array}{l}\text { No obvious effects of English exposure on consonants and syllable structures in Spanish } \\
\text { were observed. Vowel errors increased following exposure to English, which has a } \\
\text { more complex vowel system than Spanish (only Spanish was observed). }\end{array}$ \\
\hline $\begin{array}{l}\text { Gildersleeve-Neumann \& } \\
\text { Wright [43] }\end{array}$ & $\begin{array}{l}14 \text { Russian-English bilinguals } \\
(3 ; 3-5 ; 7)\end{array}$ & $\begin{array}{l}\text { Bilinguals produced statistically significantly higher rates of substitution errors (both } \\
\text { consonants and vowels) compared to the monolingual control group. Bilinguals also } \\
\text { produced Russian-influenced speech sounds in the production of English words (only } \\
\text { English was investigated). }\end{array}$ \\
\hline Goldstein \& Washington [25] & $\begin{array}{l}12 \text { simultaneous Spanish-English } \\
\text { bilinguals }(4 ; 0-4 ; 11)\end{array}$ & $\begin{array}{l}\text { Bilinguals showed more advanced phonological skills in English, compared to their } \\
\text { monolingual counterparts. The opposite pattern was observed in Spanish, in which a } \\
\text { higher occurrence of error patterns was produced by bilinguals than monolingual } \\
\text { Spanish-speaking children. }\end{array}$ \\
\hline Goldstein et al. [20] & $\begin{array}{l}15 \text { Spanish-English bilinguals } \\
\text { aged } 5 ; 0-5 ; 5\end{array}$ & $\begin{array}{l}\text { Bilingual children produced similar error patterns compared to their monolingual } \\
\text { counterparts. Atypical error patterns by monolingual standards were uncommon in } \\
\text { bilingual children. }\end{array}$ \\
\hline Goldstein \& Bunta (2011) & $\begin{array}{l}\text { Ten Spanish-English bilinguals } \\
\text { with mean age of 6;0 }\end{array}$ & $\begin{array}{l}\text { Bilinguals showed more advanced phonological skills in English than the monolingual } \\
\text { control group. There were no significant differences in the percentage of occurrence for } \\
\text { error patterns in Spanish between the bilinguals and the monolingual control group. }\end{array}$ \\
\hline Grech \& Dodd [16] & $\begin{array}{l}92 \text { Maltese-English bilinguals } \\
(2 ; 0-6 ; 0)\end{array}$ & $\begin{array}{l}\text { Bilinguals produced similar error patterns to monolingual Maltese-speaking children up } \\
\text { to the age of four years. Bilinguals produced fewer error patterns beyond the age of } \\
\text { four years than the monolingual children, suggesting a more rapid acquisition of } \\
\text { phonological competence by the bilinguals (only Maltese was investigated). }\end{array}$ \\
\hline Ha et al. [45] & $\begin{array}{l}\text { Three sequential Korean-English } \\
\text { bilingual children, aged } 11 \text { years, } \\
3 ; 10 \text { and 6;0 }\end{array}$ & $\begin{array}{l}\text { No error patterns in Korean were identified, even for the child aged 3;10. In English, } \\
\text { vowel errors were common in all children and stopping and cluster reduction persisted } \\
\text { beyond the age expected of monolingual children. }\end{array}$ \\
\hline Holm \& Dodd [30] & $\begin{array}{l}\text { Two sequential Cantonese-English } \\
\text { bilinguals followed from 2;3-3;1 } \\
\text { and 2;9-3;5 }\end{array}$ & $\begin{array}{l}\text { Children produced error patterns (in both languages) considered atypical in their } \\
\text { monolingual counterparts, following the introduction of English. }\end{array}$ \\
\hline Holm \& Dodd [26] & $\begin{array}{l}40 \text { sequential Cantonese-English } \\
\text { bilinguals }(2 ; 2-5 ; 7)\end{array}$ & $\begin{array}{l}\text { Some (but not all) bilinguals produced error patterns that would indicate delayed or } \\
\text { atypical development in monolingual children in both languages. }\end{array}$ \\
\hline Kim et al. [17] & $\begin{array}{l}28 \text { Japanese-Korean bilinguals } \\
\text { with mean age of } 8.2 \text { years }\end{array}$ & $\begin{array}{l}\text { Bilinguals produced error patterns typical of monolingual Korean-speaking children but at } \\
\text { a much higher rate and much longer than their monolingual counterparts (i.e. delayed). } \\
\text { Bilinguals also produced a greater number of error patterns than the monolingual } \\
\text { control group (only Korean was investigated). }\end{array}$ \\
\hline
\end{tabular}


Table 1. Continued

\begin{tabular}{|c|c|c|}
\hline Study & Participants & Major findings \\
\hline Law \& So [19] & $\begin{array}{l}100 \text { simultaneous Cantonese- } \\
\text { Putonghua bilinguals }(2 ; 6-4 ; 11)\end{array}$ & $\begin{array}{l}\text { Error patterns were similar to their monolingual counterparts. Phonological interference } \\
\text { was rare. Language dominance influenced production of error patterns. }\end{array}$ \\
\hline Lin \& Johnson [18] & $\begin{array}{l}24 \text { sequential Mandarin } \\
\text { (Putonghua)-English bilinguals } \\
\text { aged four and five years }\end{array}$ & $\begin{array}{l}\text { Children did not show delayed error patterns in either language compared to their } \\
\text { monolingual counterparts. There were no atypical error patterns in Mandarin but some } \\
\text { Mandarin-influenced error patterns in English. }\end{array}$ \\
\hline Morrow et al. [27] & $\begin{array}{l}19 \text { English language learners }(5 ; 0- \\
7 ; 6) \text { with various first languages }\end{array}$ & $\begin{array}{l}\text { No atypical error patterns were reported but they produced typical error patterns at a } \\
\text { higher rate. Stopping and cluster reduction were present beyond 4;6, which would be } \\
\text { indicative of phonological delay by monolingual standards (only English was } \\
\text { investigated). }\end{array}$ \\
\hline Prezas et al. [28] & $\begin{array}{l}56 \text { sequential Spanish-English } \\
\text { bilinguals }(4 ; 0-5 ; 8)\end{array}$ & $\begin{array}{l}\text { No atypical error patterns reported but bilingual children had higher percentages of } \\
\text { occurrence than monolingual counterparts. There was no difference between boys and } \\
\text { girls. }\end{array}$ \\
\hline Salameh et al. [31] & $\begin{array}{l}\text { Ten Swedish-Arabic bilinguals } \\
(3 ; 11-6 ; 7)\end{array}$ & $\begin{array}{l}\text { Bilingual children produced error patterns which would be considered atypical in their } \\
\text { monolingual counterparts (e.g. consonant insertion). }\end{array}$ \\
\hline So \& Leung [29] & $\begin{array}{l}40 \text { Cantonese-Putonghua } \\
\text { bilinguals }(2 ; 6-5 ; 6)\end{array}$ & $\begin{array}{l}\text { Bilingual children produced error patterns that would indicate delayed or atypical } \\
\text { development in monolingual children. Bilinguals also had persisting vowel errors, } \\
\text { reflecting a transfer of vowel segments from one language to another. }\end{array}$ \\
\hline
\end{tabular}

from a previous study by Goldstein and Washington [21]. Comparing the error patterns produced by simultaneous Spanish-English bilingual children in Brice, Carson [24] and sequential Spanish-English bilingual children of the same age group in Prezas, Hodson [29], no obvious differences can be found. One exception is Morrow, Goldstein [28] who found that the earlier exposure to a second language was associated with more advanced phonological skills in sequential bilingual children. The length of duration of second language exposure was also associated with advanced phonological skills. The number of studies directly addressing the impact of the age of second language acquisition on error production is limited.

The third potential factor is phonological typology. To account for both 'atypical' and 'delayed' error patterns in bilingual children, the literature has offered explanations relating to differences in phonological typologies in the languages to which bilingual children are exposed [e.g. 19,23,25,27,29,31]. According to Dodd, So [25], bilingual children produce 'atypical' error patterns when the languages to which they are exposed markedly differ in the constraints that limit the segmentation of speech signals. All studies on Cantonese-English bilingual children have consistently reported that the bilingual children produce error patterns atypical of their monolingual counterparts [25,27,31]. These findings appear to support the notion that differences in phonological typology play a role in reorganisation of phonological systems whose processes are manifested as 'atypical' error patterns. On the other hand, in Spanish-English bilingual children, GildersleeveNeumann, Kester [26] suggested the bilingual children produced 'atypical' and 'delayed' error patterns, while Goldstein, Fabiano [20] found that there were no obvious differences between bilingual children and monolingual children. The same discrepancy between studies of the same language pair was also documented with Cantonese-Putonghua bilingual children [19,30]. Furthermore, Lin and Johnson [18] found that Putonghua-English bilingual children did not produce 'atypical' error patterns, even though the Putonghua and English phonologies could be argued to have marked typological differences. Whether the difference in phonological typology is a factor influencing production of error patterns in bilingual children requires further investigation.

\section{The current study}

The primary aim of the current study is to describe the type of errors produced by one of less studied bilingual populations, Korean-English bilingual (KEB) children. The type of errors produced by KEB children will be compared to the available monolingual data for ME [6] and monolingual Korean-speaking (MK) children [39]. Before we outline the Methodology, we first provide brief descriptions of Korean and English phonologies and error patterns in ME and MK children.

\section{Korean and English phonologies}

Table 2 compares Korean and English phonologies. Of note is 
Table 2. Comparison of Korean and English phonologies

\begin{tabular}{|c|c|c|}
\hline & Korean & English \\
\hline \multicolumn{3}{|c|}{ CONSONANTS } \\
\hline Stops & $p, p^{*}, p^{h}, t, t^{*}, t^{h}, k, k^{*}, k^{h}$ & $p, b, t, d, k, g$ \\
\hline Affricates & ts, $\mathrm{ts}^{*}, \mathrm{ts}^{\mathrm{h}}$ & ty, ds \\
\hline Fricatives & $s, s^{*}, h$ & $f, v, \theta, \partial, s, z, \int, z, h$ \\
\hline Nasals & $n, m, y$ & $\mathrm{n}, \mathrm{m}, \mathrm{y}$ \\
\hline Liquids & I & $\mathrm{I}, \mathrm{I}$ \\
\hline Glides & No phonemic glides & $j, w$ \\
\hline \multicolumn{3}{|l|}{ SYLLABLES } \\
\hline Clusters & No consonant clusters within a syllable & Up to three consonants as onset and four consonants in coda position \\
\hline Onset & All consonants permitted except for $/ \mathrm{y} /$ & All consonants permitted except for /y/ \\
\hline Coda & Only lax stops, nasals and liquid permitted & All consonants permitted except for /. , j, w, h/ \\
\hline
\end{tabular}

the three-way phonemic distinction by the degree of tenseness and aspiration in Korean stops and affricates [40]. Between voiced segments, the lax series (/p, t, k, ts/) can be voiced [41]. While voicing results in a phonemic contrast in English, (e.g. /pai/ vs. /bai/), in Korean [p] and [b] are allophonic variations of a phoneme, /p/. The aspirated segments $\left(/ \mathrm{p}^{\mathrm{h}}, \mathrm{t}^{\mathrm{h}}, \mathrm{k}^{\mathrm{h}}, \mathrm{ts} /\right)$ and the tense segments $\left(/ \mathrm{p}^{*}, \mathrm{t}^{*}, \mathrm{k}^{*}, \mathrm{ts} /\right)$ are not voiced. Korean stops in word final position are always unreleased an unaspirated. The slight puff of air realised in English word final stops is never observed in Korean [40,41]. It is also of importance for our later discussion to note that English affricates are post-alveolar, while Korean affricates are alveolar [42-44]. Korean alveolar fricatives have a two-way distinction $\left(/ \mathrm{s}, \mathrm{s}^{*} /\right)$ and they are never voiced, but $/ \mathrm{s} /$ is palatalised before high front vowel [40]. The Korean liquid, /l/, is realised as [l] in word final position but as $[\mathrm{r}]$ in word initial or intervocalic position [40].

Kim [39] identified five typical, developmental error patterns in MK children aged between 3;0 and 6;5. The most persisting error pattern was dentalisation of alveolar fricatives. Even in the age group of $6 ; 0-6 ; 5,20 \%$ of the MK children were producing dentalisation. Stopping of fricatives and affricates was typical till 4;11. Affrication of alveolar stops and fricatives was typical till 4;5. Typical simplification of word medial cluster was also typical till 4;5. Typical simplification of word medial cluster refers to word medial syllable final deletion (e.g. [ho.ra.i] for /ho.lay.i/), adjacent regressive assimilation (e.g. [tshin.de] for /tshim.de/) or coalescence. Simplification of liquid, in which the liquid is deleted (e.g. [ko.e] for /ko.le/) or realised as a glide (e.g. [ko.je] for /ko.le/), was typical till 3;11. In younger children (aged between 2;6 and 2;11), reduplication, consonant harmony, word final consonant deletion, tensification of lax or aspirated segments (e.g. [p*o.t*o] for / $\mathrm{p}^{\mathrm{h}} \mathrm{o.to} /$ ), fronting of velar consonants, nasalisation of liquid and stopping of liquid were identified as additional error patterns.

Dodd, Holm [6] identified six typical, developmental error patterns found in ME children aged between 3;0 and 5;11; gliding, deaffrication, cluster reduction, fronting, weak syllable deletion and stopping. No error patterns were reported in six-year-old children. Gliding, in which liquids are realised as glides, was the most persisting error pattern, only resolved after 5;11. Deaffrication and cluster reduction were typical until $4 ; 11$. Deaffrication refers to modification of the affrication feature [6] and its examples include [ $\left.\int\right]$ for $/ \mathrm{t} f /$ and $[\mathrm{dz}]$ for $/ \mathrm{d} z /$. Cluster reduction refers to deletion of a segment in the consonant cluster. Fronting of velar consonants and weak syllable deletion are typical until 3;1l and stopping of fricatives till 3;5. In two-year-old ME children, additional error patterns of final consonant deletion, voicing error, fronting fricatives, assimilation and vowel errors were identified as typical, all of which are expected to be resolved by the age of three years [45].

\section{METHODS}

\section{Participants}

Fifty-two typically developing KEB children growing up in New Zealand participated in the current study. Table 3 illustrates the characteristics of the participants along with their unique participant code. No children had a known condition impacting on their speech and language development. Children were considered bilingual if they were receiving regular and consistent input in both languages and the parents re- 
Table 3. Characteristics of the participants

\begin{tabular}{|c|c|c|c|c|c|}
\hline $\begin{array}{l}\text { Participant } \\
\text { code }\end{array}$ & $\mathrm{Age}^{\mathrm{a}}$ & Gender & $\begin{array}{c}\text { Birth country } \\
\text { (age of } \\
\text { arrival }^{b} \text { ) }\end{array}$ & $\begin{array}{l}\text { Age of } \\
\text { English } \\
\text { exposure }^{b}\end{array}$ & $\begin{array}{c}\text { Proportion } \\
\text { of } \\
\text { language } \\
\text { exposure }\end{array}$ \\
\hline $3 A$ & $3 ; 0$ & $M$ & New Zealand & 0 & 13.00 \\
\hline $3 B$ & $3 ; 1$ & $M$ & New Zealand & 36 & 7.17 \\
\hline $3 C$ & $3 ; 1$ & $M$ & New Zealand & 34 & 4.06 \\
\hline $3 D$ & $3 ; 2$ & $\mathrm{~F}$ & New Zealand & 0 & 0.69 \\
\hline $3 \mathrm{E}$ & $3 ; 4$ & $M$ & Korea (35) & 36 & 1.44 \\
\hline $3 \mathrm{~F}$ & $3 ; 6$ & $\mathrm{~F}$ & New Zealand & 0 & 3.09 \\
\hline $3 G$ & $3 ; 7$ & $F$ & Korea (12) & 41 & 4.06 \\
\hline $3 \mathrm{H}$ & $3 ; 9$ & $\mathrm{~F}$ & New Zealand & 0 & 0.31 \\
\hline 31 & $3 ; 9$ & M & New Zealand & 0 & 2.50 \\
\hline $3 \mathrm{~J}$ & $3 ; 11$ & $M$ & New Zealand & 0 & 2.37 \\
\hline $3 K$ & $3 ; 11$ & $M$ & New Zealand & 0 & 2.28 \\
\hline $3 \mathrm{~L}$ & $3 ; 11$ & $\mathrm{~F}$ & New Zealand & 27 & 2.16 \\
\hline $4 \mathrm{~A}$ & $4 ; 0$ & $M$ & New Zealand & 34 & 1.33 \\
\hline $4 \mathrm{~B}$ & $4 ; 3$ & $\mathrm{~F}$ & Korea (7) & 7 & 4.83 \\
\hline $4 C$ & $4 ; 3$ & $\mathrm{~F}$ & New Zealand & 0 & 0.66 \\
\hline $4 \mathrm{D}$ & $4 ; 7$ & $M$ & Korea (9) & 9 & 3.15 \\
\hline $4 \mathrm{E}$ & $4 ; 8$ & $\mathrm{~F}$ & Korea (35) & 46 & 5.05 \\
\hline $4 \mathrm{~F}$ & $4 ; 8$ & $\mathrm{~F}$ & New Zealand & 12 & 1.77 \\
\hline $4 \mathrm{G}$ & $4 ; 11$ & M & New Zealand & 0 & 1.03 \\
\hline $4 \mathrm{H}$ & $4 ; 11$ & $\mathrm{M}$ & New Zealand & 0 & 2.50 \\
\hline $5 A$ & $5 ; 0$ & $M$ & New Zealand & 39 & 2.03 \\
\hline $5 B$ & $5 ; 1$ & $\mathrm{~F}$ & Korea (34) & 38 & 1.19 \\
\hline $5 C$ & $5 ; 1$ & $\mathrm{~F}$ & New Zealand & 0 & 1.80 \\
\hline $5 \mathrm{D}$ & $5 ; 1$ & $\mathrm{~F}$ & Korea (3) & 24 & 1.33 \\
\hline $5 \mathrm{E}$ & $5 ; 3$ & $\mathrm{~F}$ & New Zealand & 0 & 0.70 \\
\hline $5 F$ & $5 ; 5$ & $\mathrm{~F}$ & New Zealand & 34 & 1.65 \\
\hline $5 \mathrm{G}$ & $5 ; 6$ & M & New Zealand & 48 & 1.11 \\
\hline $5 \mathrm{H}$ & $5 ; 6$ & $\mathrm{~F}$ & New Zealand & 60 & 1.28 \\
\hline 51 & $5 ; 6$ & $\mathrm{~F}$ & New Zealand & 0 & 2.38 \\
\hline $5 J$ & $5 ; 8$ & $M$ & New Zealand & 18 & 0.37 \\
\hline $5 K$ & $5 ; 8$ & $\mathrm{~F}$ & New Zealand & 0 & 1.28 \\
\hline $5 \mathrm{~L}$ & $5 ; 10$ & $\mathrm{~F}$ & Korea (45) & 36 & 0.59 \\
\hline $5 \mathrm{M}$ & $5 ; 11$ & M & New Zealand & 27 & 1.86 \\
\hline $6 \mathrm{~A}$ & $6 ; 0$ & $M$ & Korea (17) & 30 & 2.27 \\
\hline $6 \mathrm{~B}$ & $6 ; 0$ & $\mathrm{~F}$ & Korea (67) & 55 & 2.72 \\
\hline $6 C$ & $6 ; 1$ & $M$ & New Zealand & 42 & 1.88 \\
\hline $6 \mathrm{D}$ & $6 ; 2$ & $M$ & New Zealand & 42 & 1.67 \\
\hline $6 \mathrm{E}$ & $6 ; 3$ & $M$ & New Zealand & 18 & 1.33 \\
\hline
\end{tabular}

Table 3. Continued

\begin{tabular}{|c|c|c|c|c|c|}
\hline $\begin{array}{l}\text { Participant } \\
\text { code }\end{array}$ & $\mathrm{Age}^{\mathrm{a}}$ & Gender & $\begin{array}{c}\text { Birth country } \\
\text { (age of } \\
\text { arrival }^{b} \text { ) }\end{array}$ & $\begin{array}{l}\text { Age of } \\
\text { English } \\
\text { exposure }^{b}\end{array}$ & $\begin{array}{c}\text { Proportion } \\
\text { of } \\
\text { language } \\
\text { exposure }\end{array}$ \\
\hline $6 F$ & $6 ; 6$ & $\mathrm{~F}$ & Korea (14) & 36 & 0.79 \\
\hline $6 G$ & $6 ; 6$ & $M$ & New Zealand & 36 & 1.71 \\
\hline $6 \mathrm{H}$ & $6 ; 6$ & M & New Zealand & 36 & 2.03 \\
\hline 61 & $6 ; 7$ & $\mathrm{~F}$ & New Zealand & 24 & 1.18 \\
\hline $6 \mathrm{~J}$ & $6 ; 9$ & $M$ & New Zealand & 0 & 0.86 \\
\hline $6 K$ & $6 ; 9$ & $\mathrm{~F}$ & New Zealand & 5 & 1.38 \\
\hline $6 \mathrm{~L}$ & $6 ; 11$ & $\mathrm{~F}$ & Korea (18) & 30 & 1.51 \\
\hline $7 \mathrm{~A}$ & $7 ; 4$ & $M$ & New Zealand & 0 & 0.70 \\
\hline 7B & $7 ; 4$ & $\mathrm{~F}$ & New Zealand & 0 & 1.35 \\
\hline $7 C$ & $7 ; 6$ & $\mathrm{~F}$ & Korea (62) & 37 & 1.23 \\
\hline $7 D$ & $7 ; 6$ & $M$ & New Zealand & 0 & 0.07 \\
\hline $7 E$ & $7 ; 6$ & $\mathrm{~F}$ & New Zealand & 0 & 0.64 \\
\hline $7 F$ & $7 ; 9$ & $\mathrm{~F}$ & New Zealand & 0 & 2.27 \\
\hline $7 \mathrm{G}$ & $7 ; 11$ & $\mathrm{~F}$ & Korea $(70)$ & 36 & 0.72 \\
\hline
\end{tabular}

ayears;months; 'in months.

ported that their children were bilingual. All children were exposed to Korean from birth, regardless of their birth country. Proportion of language exposure was calculated by the total hours of Korean language exposure divided by the total hours of English language exposure in a child's average week [46]. The greatest amount of relative exposure to the Korean language was the home environment for all children. Secondary sources of Korean language exposure included weekend Korean language school $(n=25)$, church $(n=20)$, regular playgroup $(\mathrm{n}=17)$, private Korean language lessons $(\mathrm{n}=19)$, private maths lessons $(n=3)$ and other extracurricular activities, including piano and Taekwondo lessons $(\mathrm{n}=16)$. All children were attending a kindergarten or a primary school where English was the language of instruction. Other sources of English language exposure included home $(n=13), \operatorname{church}(n=7)$, regular playgroup $(\mathrm{n}=8)$, private English language lessons $(\mathrm{n}=2)$ and other extracurricular activities $(\mathrm{n}=19)$.

\section{Material and procedure}

The Diagnostic Evaluation of Articulation and Phonology [47] and the Assessment of Phonology and Articulation for Children [48] were used to obtain single word simples in English and Korean, respectively. All children completed these two assessment tools with the first author, a KEB speaker. Children's responses were audio-recorded using a digital voice re- 
corder. Children's responses were phonetically transcribed by the first author. Two independent transcribers transcribed $10 \%$ of the data. The percentages of agreement between the first author and the independent transcribers were $95.0 \%$ for English and $96.4 \%$ for Korean. The disagreements were discussed with other independent transcribers who were native speakers of each language to determine the final transcriptions to be used for analysis.

\section{Analysis}

The analysis was conducted separately for each language. The speech errors were initially codified according to the type of error (e.g. stopping), the target segment affected (e.g. /f/ to [t]) and word position and subsequently categorised according to common occurrences. The small sample size of the current study limited us to determine error patterns by using the criterion described in these monolingual studies. The error types that were produced at least three or five times by individual children are referred to as common error types.

We also compared the common error types in the KEB bilingual children with those found in the monolingual children $[6,39]$. Bilingual children were classified into one of four groups for each of their languages; (1) those who produced common error types atypical of monolingual children ('atypical), (2) those who produced common error types typical of monolingual children but produced beyond the age at which the common error types were expected to be resolved in monolingual children ('delayed'), (3) those who produced common error patterns comparable with monolingual children of the same age group ('the same'), and (4) those whose production of common error types was considered more advanced than monolingual children ('advanced'). We conducted Kruskal-Wallis one-way analysis of variance (ANOVA) and Chi-square $\left(\chi^{2}\right)$ test to investigate whether there were any factors differentiating these four groups of bilingual children for each of their languages. The factors examined included the proportion of language exposure, as reviewed in the Introduction, and those that were identified as potentially influential in monolingual children, including age, gender and parental education $[6,49]$.

\section{RESULTS}

\section{Common error types in English}

Fifteen common error types were identified in English (Table 4). Common error types in English for individual children are summarised in Table 5. Shaded cells denote the common error types that were produced at least three times but fewer than five times. Crossed-out cells denote those that were produced at least five times by individual children.

\section{Common error types in Korean}

Table 6 lists the 17 common error types in Korean and Table 7 summarises the frequency for individual children. The shaded

Table 4. Common error types in English

\begin{tabular}{|c|c|c|}
\hline Common error type & Description & Example \\
\hline Cluster reduction (CR) & Consonant cluster within a syllable is reduced & [plaf] for /splas/ \\
\hline Cluster vowel epenthesis (CVE) & Insertion of a vowel in the consonant cluster & [sinerk] for /snerk/ \\
\hline Cluster reduction at syllable boundary (CRSB) & Consonant cluster at the syllable boundary is reduced & [helikptə] for /helikpptə/ \\
\hline Gliding of liquid (GLIDE) & Liquids are realised as [w] & [twein] for /tiein/ \\
\hline Stopping of fricative (STOP) & Fricative consonant is realised as stop & [ped4] for /feðə/ \\
\hline Affrication (AFF) & Alveolar or palatal fricative consonant is realised as affricate & [tfip] for /Jip/ \\
\hline Fronting (FRONT) & Velar stop or nasal is realised as alveolar stop or nasal, respectively & [twin] for /kwin/ \\
\hline Dentalisation (DENTAL) & Alveolar fricative consonants are realised as interdental consonants & {$[\theta \mathrm{p} \theta \mathrm{Id} z]$ for /spsidz/ } \\
\hline Depalatalisation (DEPAL) & Palatal consonants become alveolar & [wots] for /wots/ \\
\hline Word final obstruent devoicing (WFDEV) & Voiced word final obstruent become voiceless & [f.spk] for /f.ngg/ \\
\hline Word final consonant deletion (WFDEL) & Word final consonant is deleted & [b.e] for /b.ed/ \\
\hline Word final vowel epenthesis (WFVOW) & Vowel is inserted word finally & {$\left[\mathrm{d} \Lambda k^{\mathrm{h}} \mathrm{i}\right]$ for $/ \mathrm{d} \Lambda \mathrm{k} /$} \\
\hline Word final consonant epenthesis (WFCON) & Consonant is inserted word finally & [treink] for /tiein/ \\
\hline Word initial consonant deletion (WIDEL) & Consonant is deleted word initially & [eb] for /web/ \\
\hline Distant assimilation (DISASS) & One sound is influenced by another & [zizəz] for /sizəz/ \\
\hline
\end{tabular}


Table 5. Production of English common error types in Korean-English bilingual children

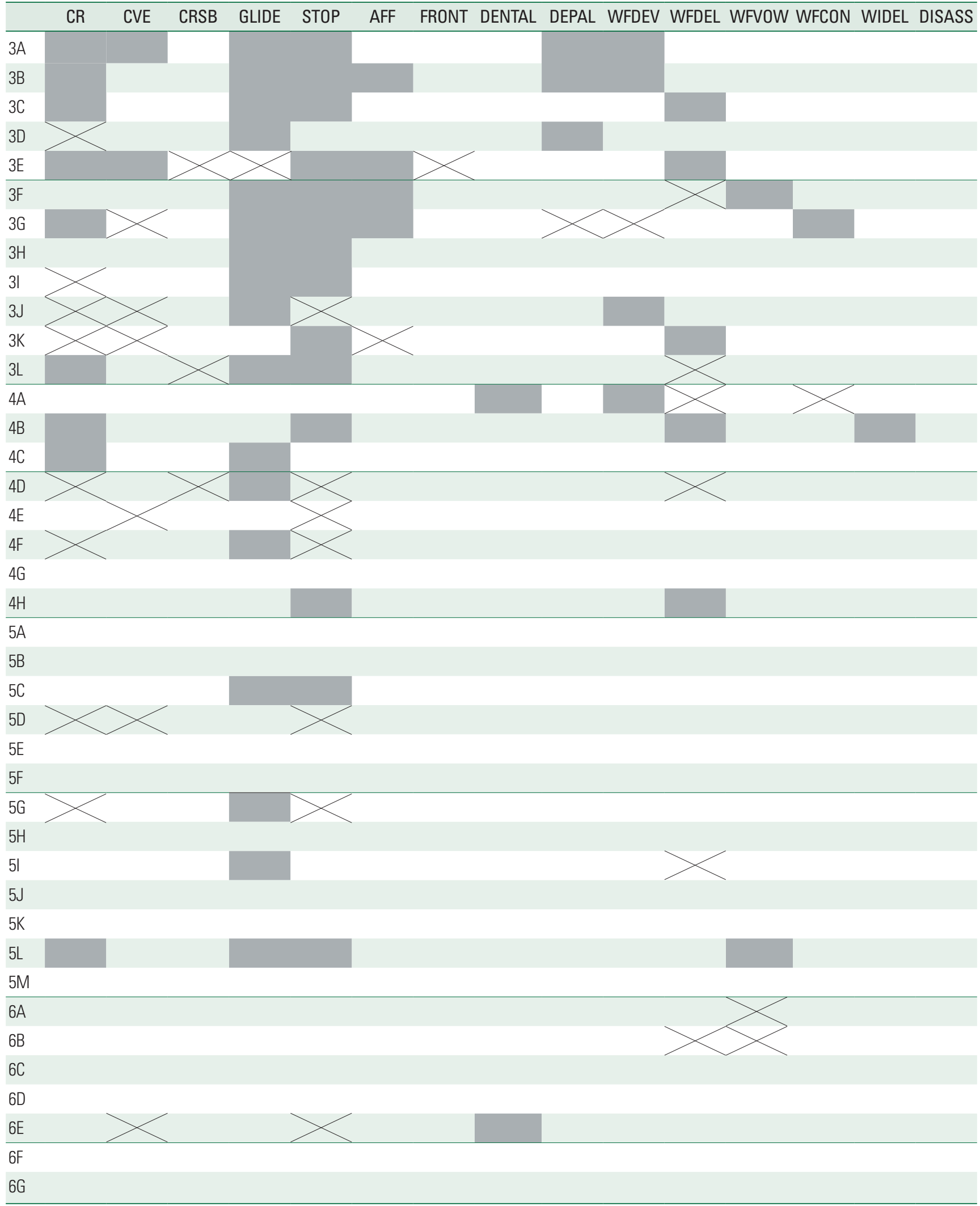


Table 5. Continued

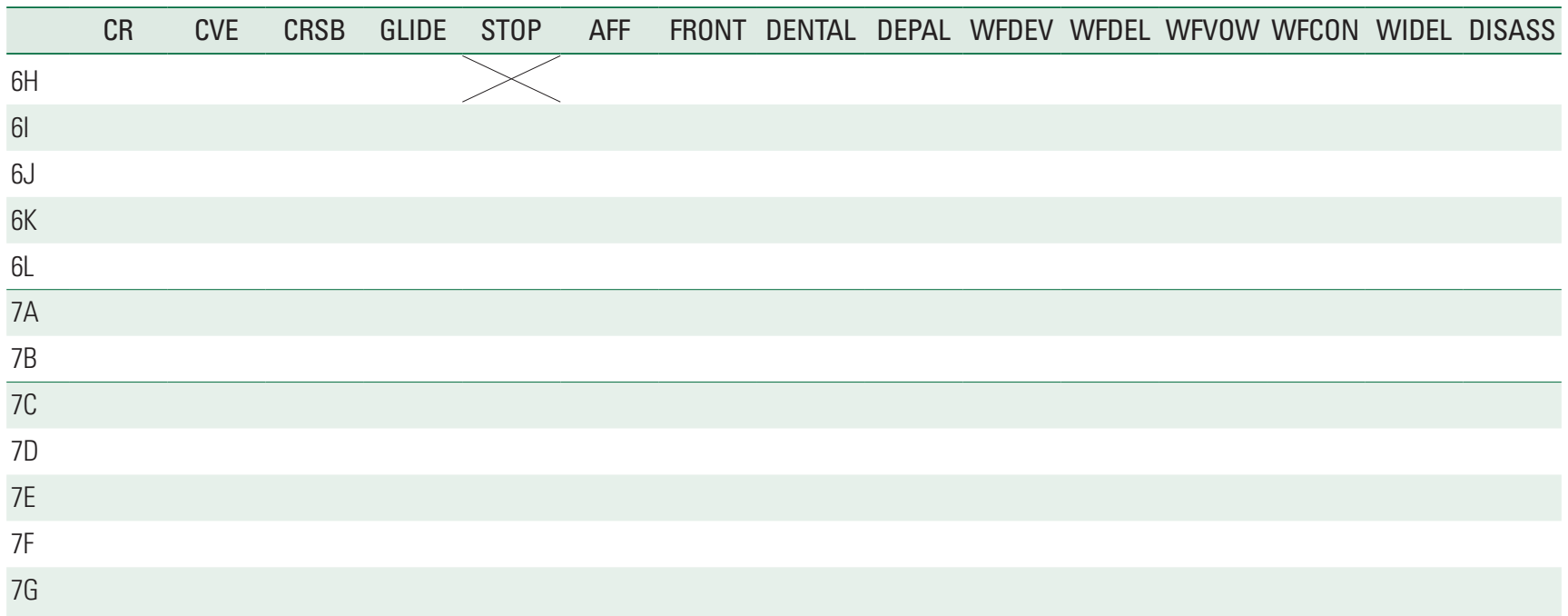

Table 6. Common error types in Korean

\begin{tabular}{|c|c|c|}
\hline Common error type & Description & Example \\
\hline Word medial syllable final consonant deletion (WMSFDEL) & Consonant in word medial syllable final position is deleted & {$\left[0 . s^{*}\right.$. su] for /ok.s*u.su/ } \\
\hline Word medial syllable initial consonant deletion (WMSIDEL) & Consonant in word medial syllable initial position is deleted & {$\left[\mathrm{m}_{\Lambda} . \mathrm{i}\right]$ for $/ \mathrm{m}_{\Lambda} . \mathrm{li} /$} \\
\hline Gliding of flap (GLIDEFLAP) & Flap is realised as [j] & [ko.je] for /ko.le/ \\
\hline Lateralisation of flap (LATFLAP) & Flap is realised as [l] & [ho.lan.i] for /ho.lan.i/ \\
\hline Stopping of flap (STOPFLAP) & Flap is realised as [d] & [ho.day.i] for /ho.lay.i/ \\
\hline Stopping of fricative (STOP) & Fricative consonant is realised as stop & [t*a] for $/ \mathrm{s}^{*} \mathrm{a} /$ \\
\hline Affrication (AFF) & Stop or fricative consonant is realised as affricate & [u.dzan] for /u.san/ \\
\hline Deaffrication (DEAFF) & Affricate consonant is realised as stop & [thim.de] for /tshim.de/ \\
\hline Fronting (FRONT) & $\begin{array}{l}\text { Velar stop or nasal is realised as alveolar stop or nasal, } \\
\text { respectively }\end{array}$ & [ho.ra.ni] for /ho.lay.i/ \\
\hline Dentalisation (DENTAL) & $\begin{array}{l}\text { Alveolar fricative consonants are realised as interdental } \\
\text { consonants }\end{array}$ & {$[\theta i . \theta 0]$ for $/$ si.so/ } \\
\hline Tensification (TENSE) & Lax or aspirated segment is realised as tense segment & [p*it] for /pit/ \\
\hline Laxing (LAX) & Tense segments are laxed & [sa] for $/ \mathrm{s}^{*} \mathrm{a} /$ \\
\hline Word final stop aspiration (WFASP) & Word final stop is aspirated & [tshek $\left.{ }^{\mathrm{h}}\right]$ for /tshek/ \\
\hline Word final consonant deletion (WFDEL) & Word final consonant is deleted & [i.p*a] for /i.p*al/ \\
\hline Word final vowel epenthesis (WFVOW) & Vowel is inserted word finally & {$\left[k^{*} 0 . d i\right]$ for $/ k^{*} 0 t /$} \\
\hline Distant assimilation (DISASS) & One sound is influenced by another at distance & [pip] for /pit/ \\
\hline Adjacent assimilation (ADJASS) & Assimilation at syllable boundary & [ham.mı.ni] for /hal.ms.ni/ \\
\hline
\end{tabular}

and crossed-out cells bear the same meaning as Table 5 .

\section{Factors influencing Error production}

Figures 1 and 2 show the proportion of KEB children whose common error types were considered 'atypical,' 'delayed,' 'the same' or 'advanced', compared to monolingual children in English and Korean, respectively. The largest proportions of children produced the common error types that would be expected of monolingual children of the same age; $40.4 \%$ and $51.9 \%$ in English and Korean, respectively. KEB children who produced common error types deemed atypical of their monolingual counterparts formed the smallest groups in both languages (17.3\% and 13.5\% in English and Korean, respectively).

In English, there was a statistically significant difference in 
Table 7. Production of Korean common error types in Korean-English bilingual children

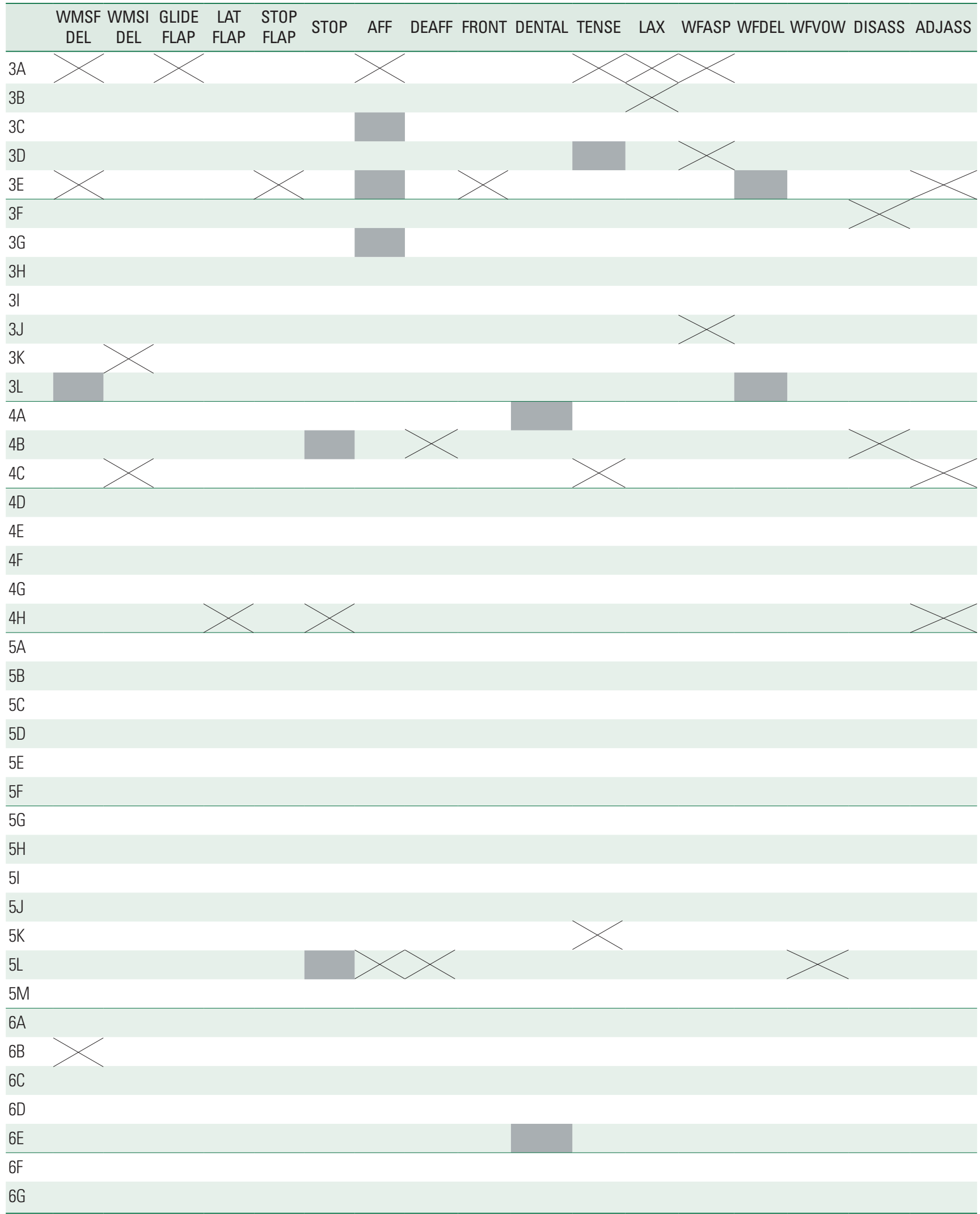


Table 5. Continued

\begin{tabular}{|c|c|c|c|c|c|c|c|c|c|}
\hline & $\begin{array}{c}\text { WMSF WMSI } \\
\text { DEL DEL }\end{array}$ & $\begin{array}{l}\text { GLIDE } \\
\text { FLAP }\end{array}$ & $\begin{array}{l}\text { LAT } \\
\text { FLAP }\end{array}$ & $\begin{array}{l}\text { STOP } \\
\text { FLAP }\end{array}$ & STOP & AFF & DEAFF FRONT DENTAL TENSE & LAX & WFASP WFDEL WFVOW DISASS ADJASS \\
\hline \multicolumn{10}{|l|}{$6 \mathrm{H}$} \\
\hline \multicolumn{10}{|l|}{61} \\
\hline \multicolumn{10}{|l|}{$6 \mathrm{~J}$} \\
\hline \multicolumn{10}{|l|}{$6 K$} \\
\hline \multicolumn{10}{|l|}{$6 \mathrm{~L}$} \\
\hline \multicolumn{10}{|l|}{$7 \mathrm{~A}$} \\
\hline \multicolumn{10}{|l|}{ 7B } \\
\hline \multicolumn{10}{|l|}{$7 C$} \\
\hline \multicolumn{10}{|l|}{$7 \mathrm{D}$} \\
\hline \multicolumn{10}{|l|}{$7 E$} \\
\hline \multicolumn{10}{|l|}{$7 F$} \\
\hline $7 G$ & & & & & & & & & \\
\hline
\end{tabular}

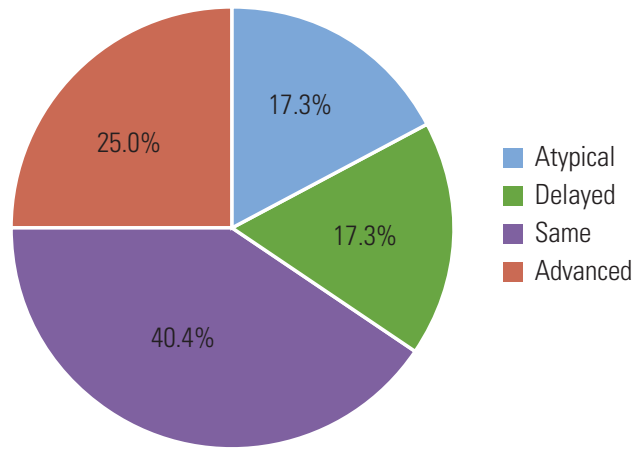

Figure 1. The proportion of Korean-English bilingual children whose English common error types were 'atypical', 'delayed', 'the same' or 'advanced', compared to monolingual English-speaking children.

age among the four groups $(\mathrm{H}=31.933, p<0.001)$ but no difference in terms of gender $\left(\chi^{2}(3, \mathrm{~N}=52)=1.042, p=0.791\right)$, age of first English language exposure $(\mathrm{H}=6.514, p=0.089)$, the proportion of language exposure $(\mathrm{H}=6.314, p=0.097)$, mother's years of education $(\mathrm{H}=0.215, p=0.975)$ and mother's age at the time of child's birth $(\mathrm{H}=2.034, p=0.566)$. In terms of the number of different contexts in which KEB children were exposed to each language, there was no difference in the number of Korean language environments $(H=7.411, p=0.060)$ but there was a statistically significant difference in the number of English language contexts $(\mathrm{H}=8.391, p=0.039)$. The mean age for each group is illustrated in Figure 3 and the mean number of English language contexts to which children were exposed is illustrated in Figure 4.

The findings regarding the Korean common error types

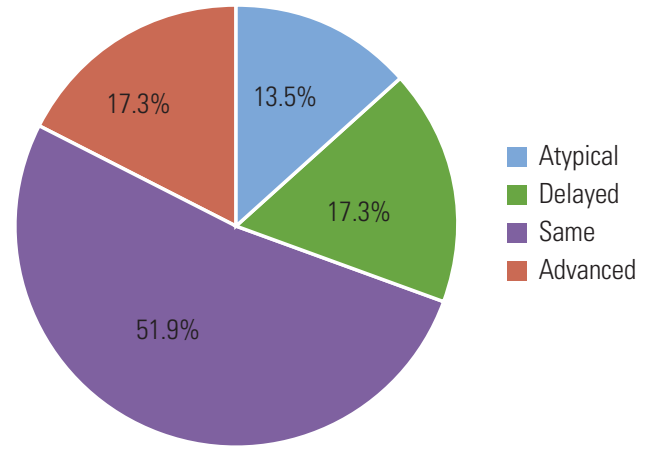

Figure 2. The proportion of Korean-English bilingual children whose Korean common error types were 'atypical', 'delayed', 'the same' or 'advanced', compared to monolingual Korean-speaking children.

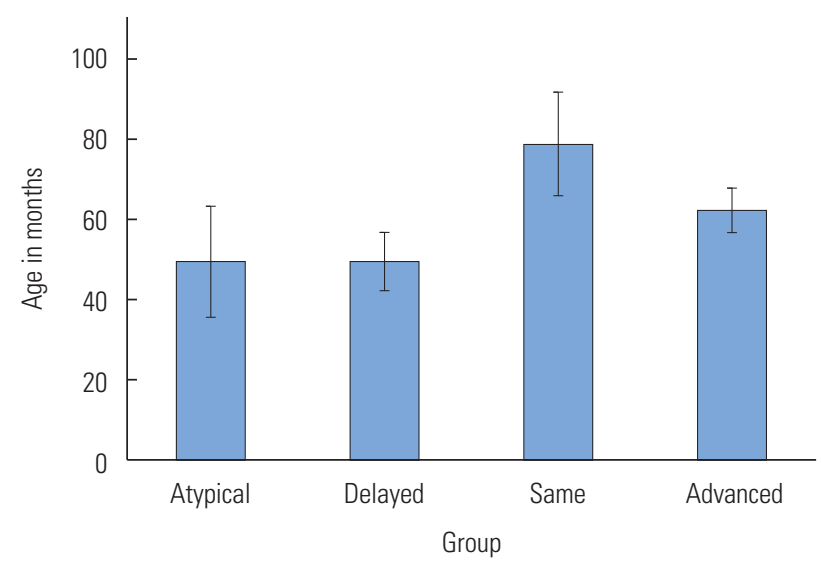

Figure 3. Group age means of Korean-English bilingual children whose production of common error types was atypical, delayed, the same and advanced compared with monolingual English-speaking children (error bars indicate standard deviations). 


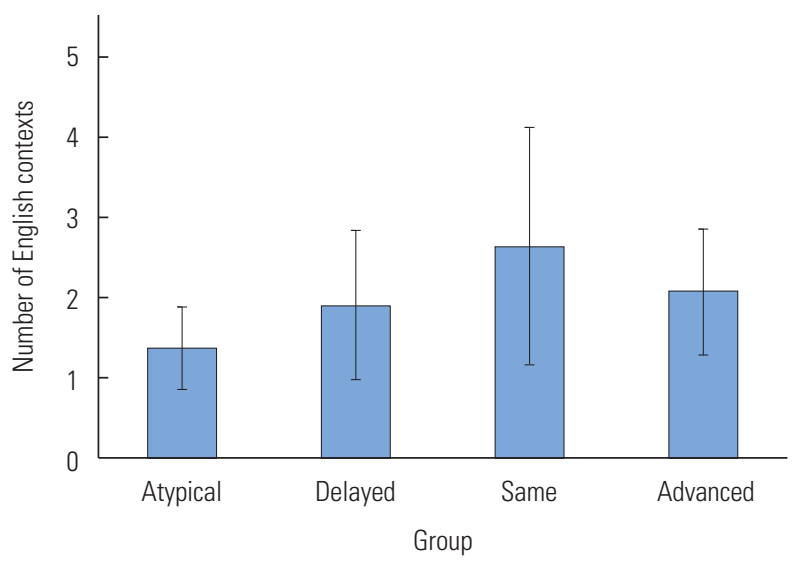

Figure 4. Mean number of different language contexts in which Korean-English bilingual were exposed to English by the four groups who produced atypical, delayed, the same and advanced common error types compared with monolingual English-speaking children (error bars indicate standard deviations).

were largely the same as English. There was a statistically significant difference among four groups in age $(\mathrm{H}=12.940$, $p=0.005)$ but not gender $\left(\chi^{2}(3, \mathrm{~N}=52)=3.033, p=0.387\right)$, age of first English language exposure $(\mathrm{H}=4.342, p=0.227)$, the proportion of language exposure $(\mathrm{H}=3.003, p=0.391)$, mother's years of education $(\mathrm{H}=0.487, p=0.922)$, and mother's age at the time of child's birth $(\mathrm{H}=4.720, p=0.193)$. There was no statistically significant difference in the number of English language contexts $(\mathrm{H}=6.889, p=0.076)$ or in the number of Korean language contexts $(\mathrm{H}=3.497, p=0.321)$ among the four groups. Age by group is illustrated in Figure 5.

\section{DISCUSSION}

The current study aimed to describe common error types in 52 KEB children. The research into bilingual phonological development has focused primarily on whether the rates and patterns of phonological development in bilingual children are the same as or different from those in monolingual children $[2,50]$. The current study suggests such group comparisons may be inadequate. Our findings are discussed below.

\section{Common error types}

The majority of KEB children produced the common error types expected of monolingual children of the same age (Figures 1 and 2). Gliding of liquids and stopping of fricatives in English, for example, reflect a developmental trajectory that would be expected in ME children. It is prevalent in younger children and the number of children who produced these errors decreased with age. For most common error types, pro-

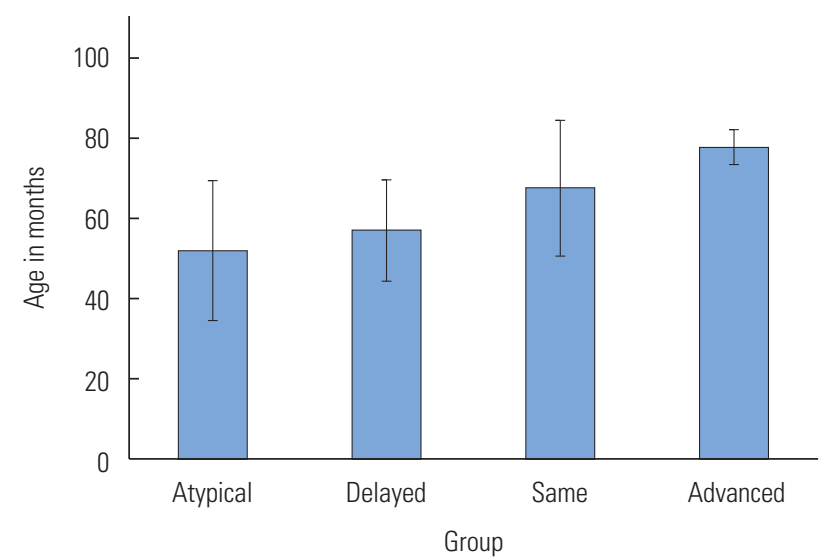

Figure 5. Group age means of Korean-English bilingual children whose production of common error types was atypical, delayed, the same and advanced compared with monolingual Korean-speaking children (error bars indicate standard deviations)

ductions of common error types are scattered and intermittent distribution across the wide age range, making it difficult to estimate the age of resolution.

Some KEB children produced 'atypical' common error types, but these children were not the majority (see Figures 1 and 2). 'Atypical' common error types could be categorised into two groups; those that are cross-linguistic in nature (cross-linguistic) and those that cannot be easily explained by the interaction of the two phonological systems (ambiguous). Table 8 shows the categorisation of the common error types atypical of monolingual children in each language.

Two subgroups of 'atypical' common error types that are cross-linguistic in nature can be identified. The first subgroup reflects developmental error patterns specific to one language in the production of the other language. KEB children produced affrication and dentalisation in English. These are typical error patterns in MK children [39] but atypical in ME children [6]. Only two children (4A and 6E) produced dentalisation in English. They were also the only two children to produce dentalisation in Korean. No other children produced dentalisation even once in either language. These two children were siblings. The siblings consistently substituted alveolar fricatives for interdental fricatives irrespective of distribution and irrespective of the elicitation method in both languages. This is consistent with the description of phonetically based articulation disorder [5]. With currently limited knowledge in phonological development in KEB children, however, it may also be possible that our findings relating to dentalisation may reflect typical phonological development in at least some KEB children. If the latter is the case, then such KEB children may 
be misdiagnosed as having an articulation disorder.

Unlike dentalisation, not all children who produced affrication in English produced affrication in Korean. Likewise, some children who produced affrication in Korean did not produce it in English. English /s/ and / $/$ / could be problematic for KEB children, because these two segments are in complementary distribution in Korean [40]. These erroneous productions could be due to both developmental and cross-linguistic effects that operate simultaneously during phonological development in bilingual children [26]. In other words, the transient and inconsistent pattern of erroneous productions of English /s/ and / $/$ / may reflect underspecified realisation rules due to the presence of two phonological systems that are being reorganised $[27,31,51]$. Such reorganisation of phonological systems is likely manifested in /s/ and $/ \mathrm{J} /$, because these two segments must be organised into two separate phonemic categories in English but into a single phonemic category in Korean [51,52].

The second subgroup of 'atypical' common error types reflects those that are influenced by the phonological features of the other language. Cluster vowel epenthesis in English is one example. It reflects the influence of Korean phonology, which does not permit consonant clusters within a syllable. Word final stop aspiration in Korean reflects the influence of the realisation rules of the English word final stops. In parallel, word final obstruent devoicing is likely influenced by the realisation rules of the Korean word final stops which are always voiceless, unreleased and unaspirated. These erroneous productions of word final consonants in both languages reflect a characteristic of bilingual phonological development in which the realisation rules specific to one language are overgeneralised to production of the other language $[31,51]$. Lateralisation of flap and laxing in Korean are also cross-linguistic in nature, as they were influenced by the realisation rules of English. English /l/ is always realised as [l], whereas Korean /l/ is realised as either [l] or [r]. The English-specific realisation rule of /l/ has likely influenced the production of Korean /l/, leading KEB children to produce $[1]$ for $[r][52,53]$.

Word final vowel epenthesis in English in KEB children also reflects the influence of the Korean phonology. Word final vowel epenthesis is one of the English loanword adaptation rules in the Korean language. Kang [54] put forward that the vowel epenthesis in English loanwords is motivated by "the maximisation of the perceptual similarity between the English input and the Korean output". It could be that the influence of Korean whose word final obstruents are always voiceless, unreleased and unaspirated is manifested in two ways in English; devoicing of word final voiced obstruents and word final vowel epenthesis. The former likely reflects realisation of English word final obstruents conforming to the realisation rules of Korean word final obstruents. The latter allows for the realisation of the word final obstruents as specified by English phonology, including soft release/aspiration and voiced consonants (e.g. [d $\left.\mathrm{k}^{\mathrm{h}} \mathrm{i}\right]$ for $/ \mathrm{d} \Lambda \mathrm{k} /$; [egi] for $/ \mathrm{eg} /$ ). Word final vowel epenthesis in Korean could be considered overgeneralisation of word final vowel epenthesis in English (Holm \& Dodd, 1999).

To date, we have not acquired sufficient information about what constitutes the characteristics of typical phonological development in KEB children. As such, we cannot suggest definitively that the common error types discussed so far necessarily reflect typical phonological development in KEB children. However, why KEB children might have produced such 'atypical' errors could be explained based on what we know about phonological development in ME and MK children and the features of English and Korean phonologies. The ambiguous common error types listed in Table 8 are more difficult to

Table 8. 'Atypical' common error types in Korean-English bilingual children

\begin{tabular}{|c|c|c|c|}
\hline & \multicolumn{2}{|c|}{ Cross-linguistic } & \multirow{2}{*}{ Ambiguous } \\
\hline & Pattern & Feature & \\
\hline \multirow[t]{3}{*}{ English } & Affrication & Word final vowel epenthesis & Word final consonant epenthesis \\
\hline & Dentalisation & Cluster vowel epenthesis & Word initial consonant deletion \\
\hline & $\begin{array}{l}\text { Cluster reduction at syllable } \\
\text { boundary* }\end{array}$ & & \\
\hline \multirow[t]{4}{*}{ Korean } & & Word final stop aspiration & Word medial syllable initial consonant deletion \\
\hline & & Lateralisation of flap & \\
\hline & & Laxing & \\
\hline & & Word final vowel epenthesis & \\
\hline
\end{tabular}

*No children produced cluster reduction at syllable boundary more than three times. 
explain solely based on cross-linguistic interactions, although some hypotheses could be postulated. Word medial syllable initial consonant deletion in Korean, for example, is not a typical, developmental error pattern in Korean or English. Word medial syllable final consonant deletion is a typical, developmental error pattern in MK children [39]. Coupled with cluster reduction in English [6], faulty overgeneralisation could have resulted in word medial syllable initial consonant deletion in Korean and cluster reduction at syllable boundary in English $[31,55]$. Word final consonant epenthesis and word initial consonant deletion in English are also difficult to explain. An explanation that accounts for word final consonant epenthesis could be postulated, considering the children who produced word final consonant epenthesis in the current study were exposed to English after Korean. Before they were exposed to English, their lexicon would have consisted of words with the maximal phonological structure of $\mathrm{C}_{1} \mathrm{VC}_{1}$ (consonant-vowelconsonant) consistent with the Korean phonology. The child's hypothesis about how a word is shaped has to be re-thought with the introduction of English that allows consonant clusters in word final position (Table 2). Having to differentiate the language-specific sets of constraints forces the child to reevaluate the previous hypothesis and generate and refine new ones that are consistent with English [31]. During this period of re-specifying the phonological systems, the child may derive false hypotheses about the phonological structure of English (e.g. $\mathrm{C}_{1} \mathrm{VC}_{1}$ for Korean and $\mathrm{C}_{1} \mathrm{VC}_{\mathrm{n}+1}$ for English) leading to word final consonant epenthesis [cf. 10]. In addition, different sets of realisation rules, as well as phonotactic constraints, on word final position for each language may mean that the segments in word final position are vulnerable [56] or fragile $[55,57]$ in the sense that they are prone to errors and difficult to master for KEB children. Note that there are several other common error types that are specifically related to word final position, including word final consonant deletion, word final obstruents devoicing and word final vowel epenthesis in KEB children in both of their languages (Tables 4 and 6). It should be clearly pointed out, however, that these ambiguous common error types might be a sign of phonological disorder in KEB children. In particular, only one child (4B) produced word initial consonant deletion, for which no reasonable explanation can be offered. Studies with a larger sample are required to investigate whether these two common error types constitute characteristics of typical phonological development in KEB children.

KEB children who produced such 'atypical' common error types were not the majority. The majority of KEB children produced the common error types expected of monolingual children of the same age group in both languages (Figures 1 and 2). Gliding of liquids in English, for example, seems to reflect a developmental trajectory that would be expected in ME children. It is prevalent in younger children and the number of children who produced gliding of liquids decreased with age. Stopping of fricatives in English also shows a similar developmental sequence, in which the common error type is progressively resolved with age, although the age of resolution of stopping of fricatives in KEB children appears to be much later than ME children. Other common error types typical of monolingual children seemed to be resolved much earlier. Weak syllable deletion in English was not identified as a common error type and none of the KEB children produced fronting of velar consonants more than three times. For most common error types, however, it is difficult to estimate the age of resolution. Affrication in Korean, for example, was produced by five three-year-old and one five-year-old KEB children, but no four-year-old KEB children. Scattered and intermittent distribution across the wide age range in the current study differs from previous monolingual studies in which the error patterns quantitatively and qualitatively decrease with age.

\section{'Delayed' common error types}

It has been almost accepted and expected that bilingual children will be delayed, compared to their monolingual counterparts. For example, Dodd, So [25] stated "delayed phonological acquisition is probably not surprising given the need to master two phonological systems in the preschool years and, perhaps proportionately less exposure to each language compared with monolingual children". In the current study, only $17.3 \%$ of KEB children showed 'delay' compared to monolingual children. However, 'delay' in the current study does not necessarily suggest that those KEB children's acquisition of phonologies was slower than monolingual children. Consider the child $4 \mathrm{H}$ (aged 4;11), who produced word final consonant deletion and stopping of fricatives in English. These error patterns are typical till 2;11 and 3;5 in ME children, respectively [45]. According to Dodd, Holm [6], gliding of liquids, deaffrication and tri-cluster reduction are typically produced in ME children aged between 4;6 and 4;11. Although $4 \mathrm{H}$ was considered 'delayed' in our analysis, because the child produced common error types that are typical of $\mathrm{ME}$ children but expected at much younger age, this apparent 'delay' does not reflect quantitatively slower rates but reflects 
qualitative differences in phonological acquisition between bilingual and monolingual children. Such findings suggest that comparing bilingual children against monolingual norms is likely to result in overgeneralised and reductive conclusions about bilingual phonological development.

\section{Factors influencing error production in bilingual children}

The current study can suggest that younger children are more likely to produce 'atypical' common error types in both of their languages and that children who are exposed to a fewer number of English language contexts are more likely to produce 'atypical' common error types in English. In the literature, language dominance, age of second language acquisition and phonological typology have been discussed as potential factors influencing error productions in bilingual children. Firstly, there was no strong evidence that language dominance in KEB children, as reflected in the proportion of language exposure [see 33], was a significant factor in either English or Korean. The current study does not support the suggestion that 'atypical' error patterns are not produced in the dominant language or that the dominant language is less influenced by bilingualism as previously suggested in the literature $[18,30]$. There were eight children who produced 'atypical' common error types belonging to the pattern subgroup as illustrated in Table 8 (3B, 3E, 3G, 3K, 3L, 4A, 4D, and $6 \mathrm{E})$, all of whom were receiving proportionately greater language input in Korean (i.e. Korean dominant). However, these errors were not produced in other Korean-dominant KEB children and the phonological features of Korean make it impossible to produce ME-specific error patterns in Korean, such as cluster reduction.

There are two aspects to consider when interpreting the non-finding of language dominance as a significant factor in the current study. Morrow, Goldstein [28] found no relationship between the use of English at home and the children's phonological skills in English, if English was the non-dominant language of the parents. The majority of the KEB children in the current study were exposed to English in their home environment but to varying extents. Although we did not directly measure the English language proficiency of their parents, Korean adults in New Zealand generally have poor English skills $[58,59]$ and have even been identified as being least competent in everyday use of English among all ethnic groups in New Zealand [60]. Exposure to non-dominant language at home environments may have little or no influence on production of error patterns in bilingual children, if the source of exposure to the non-dominant language is the parents who are not dominant in that language and therefore are not able to provide a robust model for bilingual children to learn and differentiate phonological systems [61,62]. In addition, the literature suggests that shared language experiences such as book reading are supportive of language development $[63,64]$. Mere exposure to language(s), reflected in language dominance, may not impose significantly on learning phonemic contrasts and reorganisation of phonological systems [e.g. 65,66]. Most KEB children were receiving secondary English language input at church or in group activities, such as soccer and swimming, in which they are more likely to be passive participants/listeners than they are actively engaged in shared language experience. Qualitative, rather than quantitative approaches to language exposure in future studies may help explicate the discrepancies in the findings related to error production and language dominance in bilingual children.

Secondly, the age of English language exposure was not a significant factor in the current study. Our findings are largely in line with previous studies. Thus far, there is little empirical evidence to support the claim that cross-linguistic effects may be more pronounced in sequential bilingual children [38] because the second language phonology is established by initially superimposing onto (and therefore influenced to a greater extent by) the existing first language phonology $[36,37]$. However, studies examining the role of age of second language acquisition have had relatively small sample sizes or unbalanced sample sizes. Future studies with a larger sample size should consider age of second language acquisition in context with other external factors, such as the proportion of language exposure and language dominance, rather than examining its influence on error production in isolation.

Finally, the differences in phonological typology between the two languages to which bilingual children are exposed have been a topic of discussion in the literature as it relates to error productions [e.g. 19,23,25,27,31]. The majority of common error types deemed atypical of monolingual children in the current study could be accounted for by interactions between English and Korean phonologies. It is possible that the features of Korean phonology have 'prevented' production of ME-specific error patterns, such as cluster reduction, rather than external factors. Specifically pertaining to production of 'atypical' error patterns in bilingual children, Dodd, So [25] suggested "... there is a cognitive mechanism that allows children to parse heard speech and derive an understanding of the constraints that limit how speech sounds may be combined to 
make up words in a particular language. When children are exposed to two languages where those constraints differ markedly... it could be predicted that atypical error patterns might arise". The current study is in partial disagreement with their claim. Explanations that are solely based on typological differences between two phonological systems seem insufficient to account for why only some KEB bilingual children produce 'atypical' error patterns while others do not. The current study could account for most 'atypical' common error types based on cross-linguistic influences. Future studies should consider whether bilingual children who produce 'atypical' error patterns do have a distinct profile of cognitive abilities compared to those who do not, as implied in Dodd, So [25].

\section{Methodological challenges and clinical implications}

Our error analysis identified 15 and 17 common error types for English and Korean, respectively. The number of common error types identified for each language in the current study is comparable to those identified in 40 Cantonese-English bilingual children aged between 2;2 and 5;7 in Holm and Dodd [27] but considerably greater than reported in monolingual children $[6,39]$. This may reflect the greater degree of variation inherent in phonological development in bilingual children compared to that in monolingual children [2]. However, there may be a methodological issue underlying the number of common error types identified in the current study, which may not be addressed simply with a larger sample size.

Error patterns are considered a clinically relevant descriptive device to represent the consistent and systematic discrepancies between adults' targets and the child's erroneous productions $[5,67,68]$. In the current study and the previous studies listed in Table 1, the target productions against which bilingual children's erroneous productions were analysed were based on correct productions by monolingual speakers. However, most adult bilingual speakers, especially those who learn a second language after the age of six years, tend to have speech that is impressionistically different from adult monolingual speakers [69-73]. According to Munro [74], impressionistically different speech in adult bilingual speakers is "a common, normal aspect of late second language acquisition". Although considerably less research has been conducted in adult bilinguals who were exposed to both languages in early childhood, Piske, MacKay [72] argued that no convincing evidence exists to suggest that adult bilinguals who were exposed to a second language early in childhood will produce monolingual-like speech. Some studies suggest that prolonged ex- posure to a second language can even lead to changes in speech production in bilingual adults' first language [e.g. $75,76]$. Whether adult bilingual speakers will have speech that is impressionistically different from monolingual speakers depends on a variety of factors, including age of second language acquisition and the extent of second language use [69,72,77]. The differences in speech production between adult bilingual and monolingual speakers can be observed in voice onset times of stops, vowel durations, prosodic features and sound substitutions [78,79 for reviews]. Flege [80] argued that sound substitutions (i.e. mispronunciations), if present, are the most readily apparent speech characteristic in bilingual speakers. For example, native German speakers learning English as a second language often devoice English word final voiced stops [81]. Lombardi [82] notes native Japanese speakers learning English tend to produce $[\mathrm{t}]$ for $/ \theta /$ in English, while native Russian speakers tend to produce $[\mathrm{s}]$ for $/ \theta /$. The 'mispronunciations' in second language learners are attributed to a systematic influence of first language phonology [79].

If we accept that speech productions between bilingual and monolingual speakers are different, the obvious implication seems to be that we should compare bilingual children's speech productions to bilingual adults' speech productions for error pattern analysis. This would require a comprehensive normative database of typical speech productions in adult bilingual speakers. However, given the considerable variations in 'typical' speech productions in bilingual adults, which are influenced by multiple factors $[72,77]$, it is highly questionable as to whether a valid comparison with bilingual adults for error pattern analysis will ever be possible. For adult KEB speakers, some studies have already been done. In the majority of these studies, however, speech in adult KEB speakers were impressionistically judged by native English speakers [e.g. 83,84]. Studies which have reported on sound substitutions in adult English language learners observed that Koreans produced [s, d] for English interdental fricatives [78] and devoiced word final voiced obstruents in English while producing word final voiceless obstruents accurately [85]. The current study also found that KEB children substituted [d] for $/ ð /$ and devoiced word final voiced consonants in English. Word final consonant devoicing found in adult German learners of English, adult Korean learners of English and KEB children is clearly cross-linguistic in nature. It is due to the systematic influence from German or Korean whose word final consonants are always realised as voiceless. It could not be suggested, however, that word final obstruent devoicing in 
KEB children, as found in the current study, is unequivocally developmental, because adult Korean learners of English produce the same type of errors.

It is difficult to determine whether there are error patterns in bilingual children that arise solely from cross-linguistic effects, rather than developmental progression. If there are error patterns in KEB children that are cross-linguistic in nature, which do not necessarily reflect developmental progression, resolution of such errors may not be strictly associated with chronological age as found in monolingual studies [e.g. 6]. If so, it will have a direct implication on how we diagnose phonological delay framed within the DDS [5] for bilingual children. It has to be questioned whether such purely cross-linguistic errors are clinically relevant. Munro [74] argued that the differences in speech characteristics between bilingual and monolingual speakers should not be considered inherently problematic but that we should accept such differences in adult bilingual speakers as a part of normal variation in human speech in a society that is increasingly becoming linguistically diverse. If certain types of 'mispronunciations' or error patterns in bilingual children result solely from cross-linguistic effects (but not developmental) and are therefore a typical characteristic of bilingual phonological development, then further studies are warranted to determine whether these errors should still be used as a clinically relevant descriptive device in assessment of children with suspected SSD and whether such errors should be targeted in therapy.

\section{CONCLUSION}

The current study reported on error production in $52 \mathrm{KEB}$ children aged between 3;0 and 7;11. Reaffirming the argument put forward in the recent systematic literature review [2], we suggest a comparison with monolingual children likely lead to reductive and overgeneralised conclusions about bilingual phonological development due to qualitative differences in phonological development between monolingual and bilingual children.

\section{CONFLICT OF INTEREST}

The author has no conflict of interests.

\section{REFERENCES}

1. Goldstein BA, McLeod S. Typical and atypical multilingual speech acquisition. In: McLeod S, Goldstein BA, editors. Multilingual aspects of speech sound disorders in children. Clevedon, UK: Multilingual Matters; 2012. p. 84-100.

2. Hambly H, Wren Y, McLeod S, Roulstone S. The influence of bilingualism on speech production: A systematic review. International Journal of Language \& Communication Disorders. 2013;48(1):124.

3. Flipsen P Jr, Bankson NW, Bernthal JE. Classification and comorbidity in speech sound disorders. In: Bernthal JE, Bankson NW, Flipsen P, Jr, editors. Articulation and phonological disorders: Speech sound disorders in children. 7th ed. Boston, MA: Pearson Education; 2013. p. 114-43.

4. Shriberg LD. Developmental phonological disorders. In: Hixon TJ, Shriberg LD, Saxman JS, editors. Introduction to communicative disorders. Englewood Cliffs, NJ: Prentice Hall; 1980. p. 262-309.

5. Dodd B. Differential diagnosis and treatment of children with speech disorder. 2nd ed. London, UK: Whurr; 2005.

6. Dodd B, Holm A, Zhu H, Crosbie S. Phonological development: A normative study of British English-speaking children. Clinical Linguistics \& Phonetics. 2003;17(8):671-643.

7. Dodd B. Differential diagnosis of pediatric speech sound disorder. Current Developmental Disorders Reports. 2014;1(3):189-196.

8. Crosbie S, Holm A, Dodd B. Cognitive flexibility in children with and without speech disorder. Child Language Teaching \& Therapy. 2009;25(2):250-270.

9. Dodd B. Differentiating speech delay from disorder: Does it matter? Topics in Language Disorders. 2011;31(2):96-111.

10. Dodd B, Leahy J, Hambly G. Phonological disorders in children: Underlying cognitive deficits. British Journal of Developmental Psychology. 1989;7(1):55-71.

11. Holm A, Farrier F, Dodd B. Phonological awareness, reading accuracy and spelling ability of children with inconsistent phonological disorder. International Journal of Language \& Communication Disorders. 2008;43(3):300-322.

12. Broomfield J, Dodd B. Is speech and language therapy effective for children with primary speech and language impairment? Report of a randomized control trial. International Journal of Language \& Communication Disorders. 2011;46(6):628-640.

13. Crosbie $S$, Holm A, Dodd B. Intervention for children with severe speech disorder: A comparison of two approaches. International Journal of Language \& Communication Disorders. 2005;40(4): 467-491.

14. Dodd B, Bradford A. A comparison of three therapy methods for children with different types of developmental disorder. International Journal of Language \& Communication Disorders. 2000; 35(2):189-209.

15. Miccio AW, Scarpino SE. Phonological analysis, phonological processes. In: Ball MJ, Perkins MR, Müller N, Howard S, editors. The handbook of clinical linguistics. Oxford, UK: Blackwell Publishing; 2008. p. 412-422.

16. Grech H, Dodd B. Phonological acquisition in Malta: A bilingual language learning context. International Journal of Bilingualism. 2008;12(3):155-171.

17. Kim JS, Lee JH, Choi YM, Kim HG, Kim SH, Lee MK, et al. Korean speech sound development in children from bilingual JapaneseKorean environments. Korean Journal of Pediatrics. 2010;53(9): 834-839. 
18. Lin LC, Johnson CJ. Phonological patterns in Mandarin-English bilingual children. Clinical Linguistics \& Phonetics. 2010;24(45):369-386.

19. Law NCW, So LKH. The relationship of phonological development and language dominance in Bilingual Cantonese-Putonghua children. International Journal of Bilingualism. 2006;10(4): 405-428.

20. Goldstein BA, Fabiano L, Washington PS. Phonological skills in predominantly English-speaking, predominantly Spanish-speaking, and Spanish-English bilingual children. Language, Speech, and Hearing Services in Schools. 2005;36(3):201-218.

21. Goldstein BA, Washington PS. An initial investigation of phonological patterns in typically developing 4-year-old Spanish-English bilingual children. Language, Speech, and Hearing Services in Schools. 2001;32(3):153-164.

22. Goldstein BA, Bunta F. Positive and negative transfer in the phonological systems of bilingual speakers. International Journal of Bilingualism. 2012;16(4):388-401.

23. Gildersleeve-Neumann CE, Peña ED, Davis BL, Kester ES. Effects on L1 during early acquisition of L2: Speech changes in Spanish at first English contact. Bilingualism: Language and Cognition. 2009;12(2):259-272.

24. Brice AE, Carson CK, Dennis O'Brien J. Spanish-English articulation and phonology of 4- and 5-year-old preschool children. Communication Disorders Quarterly. 2009;31(1):3-14.

25. Dodd B, So LKH, Li W. Symptoms of disorder without impairment: The written and spoken errors of bilinguals. In: Dodd B, Campbell R, Worrall L, editors. Evaluating theories of language: Evidence from disordered communication. London, UK: Whurr; 1996. p. 119-136.

26. Gildersleeve-Neumann CE, Kester ES, Davis BL, Peña ED. English speech sound development in preschool-aged children from bilingual English-Spanish environments. Language, Speech, and Hearing Services in Schools. 2008;39(3):314-328.

27. Holm A, Dodd B. Phonological development and disorders in bilingual children acquiring Cantonese and English. In: Zhu H, Dodd B, editors. Phonological development and disorders in children: A multilingual perspective. Clevedon, UK: Multilingual Matters; 2006. p. 286-325.

28. Morrow A, Goldstein BA, Gilhool A, Paradis J. Phonological skills in English language learners. Language, Speech, and Hearing Services in Schools. 2014;45:26-39.

29. Prezas RF, Hodson BW, Schommer-Aikins M. Phonological assessment and analysis of bilingual preschoolers' Spanish and English word productions. American Journal of Speech-Language Pathology. 2014;23:176-185.

30. So LKH, Leung CSS. Phonological development of CantonesePutonghua bilingual children. In: Zhu H, Dodd B, editors. Phonological development and disorders in children: A multilingual perspective. Clevedon, UK: Multilingual Matters; 2006. p. 413-428.

31. Holm A, Dodd B. A longitudinal study of the phonological development of two Cantonese-English bilingual children. Applied Psycholinguistics. 1999;20:349-376.

32. Salameh EK, Nettelbladt U, Norlin K. Assessing phonologies in bilingual Swedis-Arabic children with and without language impairment. Child Language Teaching and Therapy. 2003;19(3):338364 .
33. Paradis J. Do bilingual two-year-olds have separate phonological systems? International Journal of Bilingualism. 2001;5(1):19-38.

34. Keshavarz $\mathrm{MH}$, Ingram $\mathrm{D}$. The early phonological development of a Farsi-English bilingual child. International Journal of Bilingualism. 2002;6(3):255-269.

35. Paradis J, Genesee F. Syntactic acquisition in bilingual children: Autonomous or interdependent? Studies in Second Language Acquisition. 1996;18:1-25.

36. Watson I. Phonological processing in two languages. In: Bialystok E, editor. Language processing in bilingual children. Cambridge, UK: Cambridge University Press; 1991. p. 25-48.

37. Wode H. Phonology in L2 acquisition. In: Felix SW, editor. Second language development: Trends and issues. Tübingen, Germany: Narr; 1980. p. 123-136.

38. Goldstein BA, Gildersleeve-Neumann C. Typical phonological acquisition in bilinguals. Perspectives on Communication Disorders and Sciences in Culturally and Linguistically Diverse Populations. 2007;14(2):11-16.

39. Kim MJ. The phonological error patterns of preschool children in the 'Korean test of articulation for children'. Korean Journal of Communication Disorders. 2006;11(2):17-31.

40. Ahn SC. Korean phonology. Yeon J, Song JJ, editors. London, UK: Saffron Books; 2009.

41. Lee I, Ramsey SR. The Korean language. Albany, NY: State University of New York Press; 2000.

42. Kim H. The place of articulation of the Korean plain affricate in intervocalic position: An articulatory and acoustic study. Journal of the International Phonetic Association. 2001;31(2):229-257.

43. Kim H. The place of articulation of Korean affricates revisited. Journal of East Asian Linguistics. 1999;8:313-347.

44. Kim H, Honda K, Maeda S. Stroboscopic-cine MRI study of the phasing between the tongue and the larynx in the Korean threeway phonation contrast. Journal of Phonetics. 2005;33(1):1-26.

45. McIntosh B, Dodd BJ. Two-year-olds' phonological acquisition: Normative data. International Journal of Speech-Language Pathology. 2008;10(6):460-469.

46. Goldstein BA, Bunta F, Lange J, Rodriguez J, Burrows L. The effects of measures of language experience and language ability on segmental accuracy in bilingual children. American Journal of SpeechLanguage Pathology. 2010;19:238-247.

47. Dodd B, Zhu H, Crosbie S, Holm A, Ozanne A. Diagnostic evaluation of articulation and phonology. London, UK: The Psychological Corporation; 2002.

48. Kim MJ, Pae S, Park C. Assessment of phonology and articulation for children. Incheon, Korea: Human Brain Research \& Consulting; 2007.

49. McLeod S. Speech sound acquisition. In: Bernthal JE, Bankson NW, Flipsen P, Jr, editors. Articulation and phonological disorders: Speech sound disorders in children. 7th ed. Boston, MA: Pearson Education; 2013. p. 58-113.

50. Unsworth S. Current issues in multilingual first language acquisition. Annual Review of Applied Linguistics. 2013;33:21-50.

51. Gildersleeve-Neumann CE, Wright KL. English speech acquisition in 3- to 5-year-old children learning Russian and English. Language, Speech, and Hearing Services in Schools. 2010;41:429-444.

52. Hulk A, Müller N. Bilingual first language acquisition at the interface between syntax and pragmatics. Bilingualism: Language and 
Cognition. 2000;3(3):227-244.

53. Nicoladis E, Paradis J. Learning to liaise and elide comme il faut: Evidence from bilingual children. Journal of Child Language. 2011;38(4):701-730.

54. Kang Y. Perceptual similarity in loanword adaptation: English postvocalic word-final stops in Korean. Phonology. 2003;20(2): 219-273.

55. Ellis R. The study of second language acquisition. 2nd ed. Oxford, UK: Oxford University Press; 2008.

56. Müller N. (In)vulnerable domains in multilingualism. Amsterdam, The Netherlands: John Benjamins; 2003.

57. Goldin-Meadow S. The resilience of recursion: A study of a communication system developed without a conventional language model. In: Wanner E, Gleitman L, editors. Language Acquisition: The State of the Art. Cambridge, MA: Cambridge University Press; 1982. p. 51-71.

58. Morris C, Vokes R, Chang S. Social exclusion and church in the experiences of Korean migrant families in Christchurch. Journal of Social Anthropology and Cultural Studies. 2007;4(2):11-31.

59. Park HJ, Anglem J. The 'transnationality' of Koreans, Korean families and Korean communities in Aotearoa New Zealand: Implications for social work practice. Aotearoa New Zealand Social Work. 2012;24(1):31-41.

60. Statistics New Zealand. Concerning language 2004 [Available from: http://www.stats.govt.nz/browse_for_stats/people_and_ communities/Language/concerning-language-2004.aspx.

61. Hoff E, Core CW. Input and language development in bilingually developing children. Seminars in Speech and Language. 2013; 34(4):215-226.

62. Hoff E, Welsh S, Place S, Ribot KM. Properties of dual language input that shape bilingual development and properties of environments that shape dual language input. In: Grüter T, Paradis J, editors. Input and experience in bilingual Development. Amsterdam, The Netherlands: John Benjamins; 2014. p. 119-140.

63. Patterson JL. Relationships of expressive vocabulary to frequency of reading and television experience among bilingual toddlers. Applied Psycholinguistics. 2002;23(4):493-508.

64. Song L, Tamis-Lemonda CS, Yoshikawa H, Kahana-Kalman R, Wu I. Language experiences and vocabulary development in Dominican and Mexican infants across the first 2 years. Developmental Psychology. 2012;48:1106-1123.

65. Bosch L, Sebastián-Gallés N. Simultaneous bilingualism and the perception of a language-specific vowel contrast in the first year of life. Language and Speech. 2003;46(2-3):217-243.

66. Best CT, McRoberts GW, Sithole NM. Examination of perceptual reorganization for nonnative speech contrasts: Zulu click discrimination by English-speaking adults and infants. Journal of Experimental Psychology: Human Perception and Performance. 1988; 14(3):345-360.

67. Peña-Brooks A, Hegde MN. Assessment and treatment of articulation and phonological disorders in children: A dual level text. Austin, TX: Pro-Ed; 2000.

68. Zhu H, Dodd B. A multilingual perspective on phonological development and disorders. In: Zhu H, Dodd B, editors. Phonological development and disorders in children: A multilingual perspective. Clevedon, UK: Multilingual Matters; 2006. p. 3-14.
69. Scovel T. A time to speak: A psycholinguistic inquiry into the critical period for human speech. New York, NY: Newbury House; 1988.

70. Major RC. Foreign accent: The ontogeny and phylogeny of second language phonology. Mahwah, NJ: Lawrence Erlbaum; 2001.

71. Major RC. Foreign accent: Recent research and theory. International Review of Applied Linguistics in Language Teaching. 1987; 25(3):185-202.

72. Piske T, MacKay IR, Flege JE. Factors affecting degree of foreign accent in an L2: A review. Journal of Phonetics. 2001;29:191-215.

73. Flege JE, Munro MJ, MacKay IRA. Factors affecting strength of perceived foreign accent in a second language. Journal of Acoustical Society of America. 1995;97(5):3125-3134.

74. Munro MJ. Foreign accent and speech intelligibility. In: Hansen Edwards JG, Zampini ML, editors. Phonology and second language acquisition. Amsterdam, The Netherlands: John Benjamins; 2008. p. 193-217.

75. Carlson PE. Field testing the theory of double semilingualism. Pittsburgh, PA: University of Pittsburgh; 1981.

76. Tomaszczyk J. On accented speech: The Polish of Polish Americans. Studia Anglica Posnaniensia Poznan. 1980;12:121-137.

77. Hansen Edwards JG. Social factors and variation in production in L2 phonology. In: Hansen Edwards JG, Zampini ML, editors. Phonology and second language acquisition. Amsterdam, The Netherlands: John Benjamins; 2008. p. 251-279.

78. Ioup G. Exploring the role of age in the acquisition of a second language phonology. In: Hansen Edwards JG, Zampini ML, editors. Phonology and second language acquisition. Amsterdam, The Netherlands: John Benjamins; 2008. p. 41-62.

79. Zampini ML. L2 speech production research: Findings, issues, and advances. In: Hansen Edwards JG, Zampini ML, editors. Phonology and second language acquisition. Amsterdam, The Netherlands: John Benjamins; 2008. p. 219-249.

80. Flege JE. The phonological basis of foreign accent: A hypothesis. TESOL Quarterly. 1981;15(4):443-455.

81. Eckman FR. Markedness and the contrastive analyses hypotheses. Language Learning. 1977;27(2):315-330.

82. Lombardi L. Second language data and constraints on manner: Explaining substitutions for the English interdentals. Second Language Research. 2003;19(3):225-250.

83. Flege JE, Birdsong D, Bialystok E, Mack M, Sung H, Tsukada K. Degree of foreign accent in English sentences produced by Korean children and adults. Journal of Phonetics. 2006;34(1):153-175.

84. Yeni-Komshian GH, Flege JE, Liu S. Pronunciation proficiency in the first and second languages of Korean-English bilinguals. Bilingualism: Language and Cognition. 2000;3(2):131-149.

85. Major RC, Faudree MC. Markedness universals and the acquisition of voicing contrasts by Korean speakers of English. Studies in Second Language Acquisition. 1996;18(1):69-90.

86. Anderson RT. Phonological acquisition in preschoolers learning a second language via immersion: A longitudinal study. Clinical Linguistics \& Phonetics. 2004;18(3):183-210.

87. Ha S, Johnson CJ, Keuhn DP. Characteristics of Korean phonology: Review, tutorial, and case studies of Korean children speaking English. Journal of Communication Disorders. 2009;42:163-179. 